\title{
Equitable Access to Higher Education: Trends, Commodification and quality dimensions in Namibia
}

\author{
Icarbord Tshabangu, ${ }^{1, *}$, Vincent Matakala ${ }^{2} \&$ Africa Zulu ${ }^{3}$ \\ ${ }^{1}$ Dept. of Educational Foundations \& Management, University of Namibia, Private Bag 13301, \\ 340 Mandume Ndemufayo Ave, Pionierspark, Windhoek, NAMIBIA \\ ${ }^{2}$ Centre for Quality Assurance \& Management, University of Namibia, Private Bag 13301, 340 \\ Mandume Ndemufayo Ave, Pionierspark, Windhoek, NAMIBIA \\ ${ }^{3}$ Dept. of Education in Languages, Humanities and Commerce, University of Namibia, Private \\ Bag 13301, 340 Mandume Ndemufayo Ave, Pionierspark, Windhoek, NAMIBIA \\ *Corresponding author: Dept. of Educational Foundations \& Management, University of \\ Namibia, Private Bag 13301, 340 Mandume Ndemufayo Ave, Pionierspark, Windhoek, \\ NAMIBIA Tel: 264-262-6037,E-mail: itshabangu@unam.na; preslica_012@hotmail.co.uk \\ Received: January 18, 2013 Accepted: March 16, 2013 Published: March 27, 2013 \\ doi:10.5296/ije.v5i1.3077ＵRL: http://dx.doi.org/10.5296/ije.v5i1.3077
}




\section{Abstract}

Higher education in most countries plays a pivotal role in the socio-economic development of citizens, hence the perception that no country can be better than the quality of its higher education system (Okwakol, 2012). It is at higher education that most governments have channelled considerable human and financial resources with a strategic view to develop human capital in the form of entrepreneurs, professionals, academics, political, religious and business leaders, who are further expected to contribute to the attainment of national goals and aspirations as embodied in Namibia's Vision 2030 (National Planning Commission Secretariat, 2004). The National Council for Higher Education (NCHE) in Namibia was thus mandated by Parliament, Act 26 of 2003, to promote access and monitor quality assurance in higher education (NCHE, 2009). In view of emergent forces of Commodification in education, the study examined the challenges on access to higher education, the rise in tuition fees and the impact this may have on quality provision and to the economy at large. Following an interpretive paradigm, the study used semi structured questionnaires through snowballing on 25 school leavers and purposive sampling which accounted for 20 grade 12 students, 10 university lecturers, 50 university students and conducted interviews on 3 university administrators on key issues inhibiting access and impacting the quality of education in Namibia's higher education. Using Critical Discourse Analysis (CDA) the study formed themes for discussion so as to describe and capture the challenges inherent. The study concluded that while Namibia has made tremendous strides in funding education in general, the funding of higher education has gradually declined over the years thus negatively impacting access to higher Education especially for students from poor backgrounds. It was also noted that the rise in higher education enrolments may be a masking of social inequalities on access well as a threat to quality provision.

Keywords: higher education; Namibia; quality; access; commodification 


\section{Introduction}

Higher education in most parts of the world plays a crucial role in equipping national citizens in a globalised but nonetheless competitive environment. Advancing a national vision such as Vision 2030 in Namibia (National Planning Commission Secretariat 2004) entails developing and channeling human and financial resources respectively so as to realise national strategic goals. In most newly independent states there has often been a concerted drive, both as a human right agenda and a national strategic vision to educate citizens who were previously disadvantaged by discriminatory forces of apartheid as in the case of Namibia (Namibia Ministry of Education, 2012). In the first instance, access to basic education becomes paramount, but as the national education system develops, efforts towards quality provision and equitable access to higher education emerge as pivotal. This study thus sought to examine challenges on equitable access to Namibia's higher Education amid forces of Commodification, where education lessens as a value to become a commodity (Stronach, Sirca, \& Dimc, 2000). The study was also mindful of the constitutional provisions on access to education as a fundamental human right (Namibia Supreme, Court, 1990).

Like most developing nations, Namibian higher education has witnessed a steady rise in enrolment coupled with reduced funding for higher education. In the last 16 years the Polytechnic of Namibia students' enrolment grew from 2245 to 12440 by 2011 thereby necessitating a greater need for funding and resource allocation (Namibia Economist, 2012; The Namibian, 2011). At the University of Namibia (UNAM) the student enrolment has sharply risen by about $60 \%$ between 2009 and 2011 (UNAM Strategic \& Physical Planning, 2012). On the contrary state funding in higher education has gradually fallen from $15 \%$ in 2007 to $8.7 \%$ in 2011 (Human Development Report, 2011; SARUA, 2012) and has continued in a gradual slide. To sustain operations, the institutions of higher learning have responded by raising fees to compensate for reduced public funding. Such a trend in higher education raises several challenges, namely quality management but more poignant for this study, equitable access.

Reduction in public funding often poses a great threat to social mobility for students from poor households and to the higher education institutions' ability to provide quality education. Though Namibia has invested heavily in education allocating about $23 \%$ to the Education ministry in the $2012 / 2013$ budget it is noted that allocation towards tertiary education has stagnated at about $8.7 \%$ as noted earlier. Such reduced allocation of funding in higher education has negatively impacted many school leavers leading to difficulties in accessing higher education, raising unemployment levels and creating a national skills gap. Lack of access to higher education may further threaten participation in social justice coupled with reduced economic performance (Barr, 2002). This study thus reviewed other cases elsewhere and further examined the perceptions of prospective higher education students such as Grade 12 and other school leavers, to assess the impact of commodification on equitable access and the quality dimensions that arise within Namibia's higher education. 


\section{Access and Namibian Higher Education}

The National Council for Higher Education (NCHE) in Namibia was established by an Act of Parliament, Higher Education Act No. 26 of 2003. The Act provides for the NCHE to promote access to higher education institutions, in addition to the promotion of the establishment of quality assurance frameworks.

Higher education in Namibia consists of a public university, a polytechnic and other public and private institutions of higher learning. According to the Higher Education Act No. 26 of 2003, post-secondary institutions do not automatically qualify to be higher education entities, although they do qualify as tertiary education institutions. The status of other post-secondary institutions such as Police Colleges, Military Schools, Nursing Schools and other specialised colleges which operate under government ministries is unclear.

Matengu (2010) noted that that the higher education system in Namibia was defective in addressing national priority needs. The report further noted that there was widespread consensus amongst key stakeholders that the Namibian higher education system was characterised by imbalances, inequalities and fragmentations, such as the wide variance between colleges, universities and the Polytechnic in resources, degree of autonomy, operational focus reporting and governance systems. It concluded that despite policies and laws that encourage access with equity, the number of staff and students from marginalised groups in higher education institutions remained low.

Economic competitiveness may occur where qualifications are aligned to national economic needs. Arguably, the single most difficult task faced by the higher education sector in most parts of Africa has been the management of social demand for access to higher education (Saint, 1992). A combination of rapidly increasing numbers of school leavers, stagnant economic growth and a surging population growth, often exert immense pressure on governments to expand higher education access (Ajayi, Goma \& Johnson, 1996).

Zeleza \& Olukushi (2004) observed that for higher education to be accessible not only to the elite, but also to the marginalised, and also to contain the growing and often violent student protests related to tuition fee increases, most governments are re-examining or introducing national student loan schemes which enable institutions of higher education to enroll even financially needy students and, in turn, ensure the institution's viability and ability to continue offering quality programmes. However, it is noted that the student loan schemes may still scare some potential students who fear to be saddled with debt. Loan defaults have also been raised as an issue of concern (Zeleza \& Olukushi, 2004).

\section{Role of Higher Education}

The benefits of higher education to a nation are far reaching, enabling governments to equip their citizens and strategically remain competitive in a largely aggressive global environment. The United Nations Educational, Scientific and Cultural Organization (UNESCO) (1998) noted some of the important features of higher education as engendering a culture of 
creativity, innovation leading to the development of knowledge reservoirs in universities. Research and technological advancement has often resided within the realm and function of higher education and critical feature for developing nations as they seek to transform their nations into knowledge based societies. Higher education also helps in reaping the gains from globalization. It is noted that globalisation has often benefited countries with a vibrant higher education system such as the USA and the UK as they have successfully exported their higher education to other countries (ESIB, 2012).

It has also been argued that higher education contributes to the deepening of democracy by producing citizens, who actively participate in the socio-political and economic life of their nations. Most higher education graduates often understand other cultures and tend to embrace diversity and pluralism leading to less conflict regionally and internationally (UNESCO, 1998). Higher education has also been credited for producing national political and civic leaders of greater capabilities and vision.

\section{Social Justice and Equitable Access}

For most newly independent states emerging from an era of apartheid where education was segregated and a preserve for the few, the need to approach access to education with a firm social justice agenda is often a necessity than a choice. Deriving from Namibia's constitution which provides for access to education as a fundamental human right (Namibia Supreme, Court, 1990), the National Council for Higher Education (NCHE) was thus mandated by Parliament, Act 26 of 2003, to promote access and monitor quality assurance in higher education (NCHE, 2009). In social justice and as reflected in this study we question as to whether access to higher education is really open to all in view of marginalised groups in society. Furlong \& Cartmel (2009) have argued that marginalized families often suffer from unfair access arrangements to higher education in comparison to the elite groups and this is further reflected in accessing graduate jobs. Trow (2005)'s historical account from elite to mass and then to universal access in higher education provides phases on how far changing notions in social justice have developed in this area. However, in view of forces of commodification in higher education, it may be argued that some higher education institutions and states have sleep-walked back to elite access that is, only concerned with shaping the mind and character of a ruling class in preparation for their roles (Brennan, 2004), leaving the lower classes to be educated to a limited level where they can perform duties cast upon them by the elite (Bailey, 2000)

\section{Commodification in Higher Education}

Commodification of education has generally been progressive world over, tearing down traditional state subsidies in some countries. The introduction of Structural Adjustment Programmes (SAPs) in mostly developing countries under the auspices of the International Monetary Fund (IMF) has also helped engender Commodification leading to students being labelled as clients and higher education institutions as 'product' providers (ESIB, 2012). 
It is noted that the challenges of equitable access in higher education are not only unique to the developing world, but affect most education systems in the world. In the United Kingdom for example universities have recently been allowed to raise tuition fees up to a maximum of $£ 9,000$ (more than N\$ 120,000) a year as from 2012 (The Economist, 2012). Even though such moves have been tempered with policies designed to promote access, the signals are clear that higher education may just have gradually become a commodity for the "haves", while condemning the "have nots" to stagnating social mobility.

ESIB, (2012) has advanced a view that it is important to challenge the Commodification of education on all levels if the value of higher education and the moral argument for equitable access is to be sustained. There must be an attack on the capitalistic use of language imposed by various multinationals on national Education ministries and United Nations agencies. Efforts to create an international higher education system based on free trade policies as evidenced in the General Agreement on Trade in Services (GATS) to the wholesale privatisation of higher education in order to reduce government expenditure as seen by some SAPs in developing countries mark a clear pattern towards deeper Commodification of higher education.

Commodification has continued to threaten state subsidies in higher education thereby pressurising public higher education institutions to privatise their business. In some countries this may raise serious concerns on the quality of higher education institutions that set up, particularly on quality assurance and accreditation of programmes in view of profit motives. The table below shows an example of countries where there has been a decline in public expenditure on higher education per student.

Table 1: \% Public expenditure on higher education

\begin{tabular}{lccc}
\hline Countries & $\mathbf{1 9 9 0 - 9 1}$ & $\mathbf{2 0 0 6}$ & Change \\
\hline UK & 40.9 & 27.6 & -13.3 \\
Australia & 50.7 & $22.5 \mathrm{a}$ & -28.2 \\
New Zealand & 67.8 & 25.2 & -42.6 \\
Chile & 27.1 & 11.6 & -15.5 \\
Czech & 45.9 & 30.4 & -15.5 \\
Nepal & 90.8 & 71.1 & -19.7 \\
Malaysia & 116.6 & 71.0 & -45.6 \\
India & 92.0 & 61.0 & -31.0 \\
Estonia & 55.9 & 18.2 & -37.7 \\
South Africa & 90.9 & 50.1 & -40.8 \\
Hungary & 81.3 & 24.3 & -57.0 \\
Jamaica & 132.3 & $40.7 \mathrm{a}$ & -91.6 \\
Regions & & & \\
High income countries & 47.1 & 29.0 & -18.1 \\
South Asia & 90.8 & 68.6 & -22.0 \\
Upper middle income & 61.8 & 23.3 & -38.5 \\
\hline
\end{tabular}




\section{Macrothink}

Decline in public expenditure on higher education per student (\% of GDP per capita) Source: World Bank, (2008)

It is noted that the fall in state subsidies has conversely led to the rise in tuition fees as higher education institutions strive to meet quality demands and stay afloat. The table below depicts the experience of South African higher education institutions.

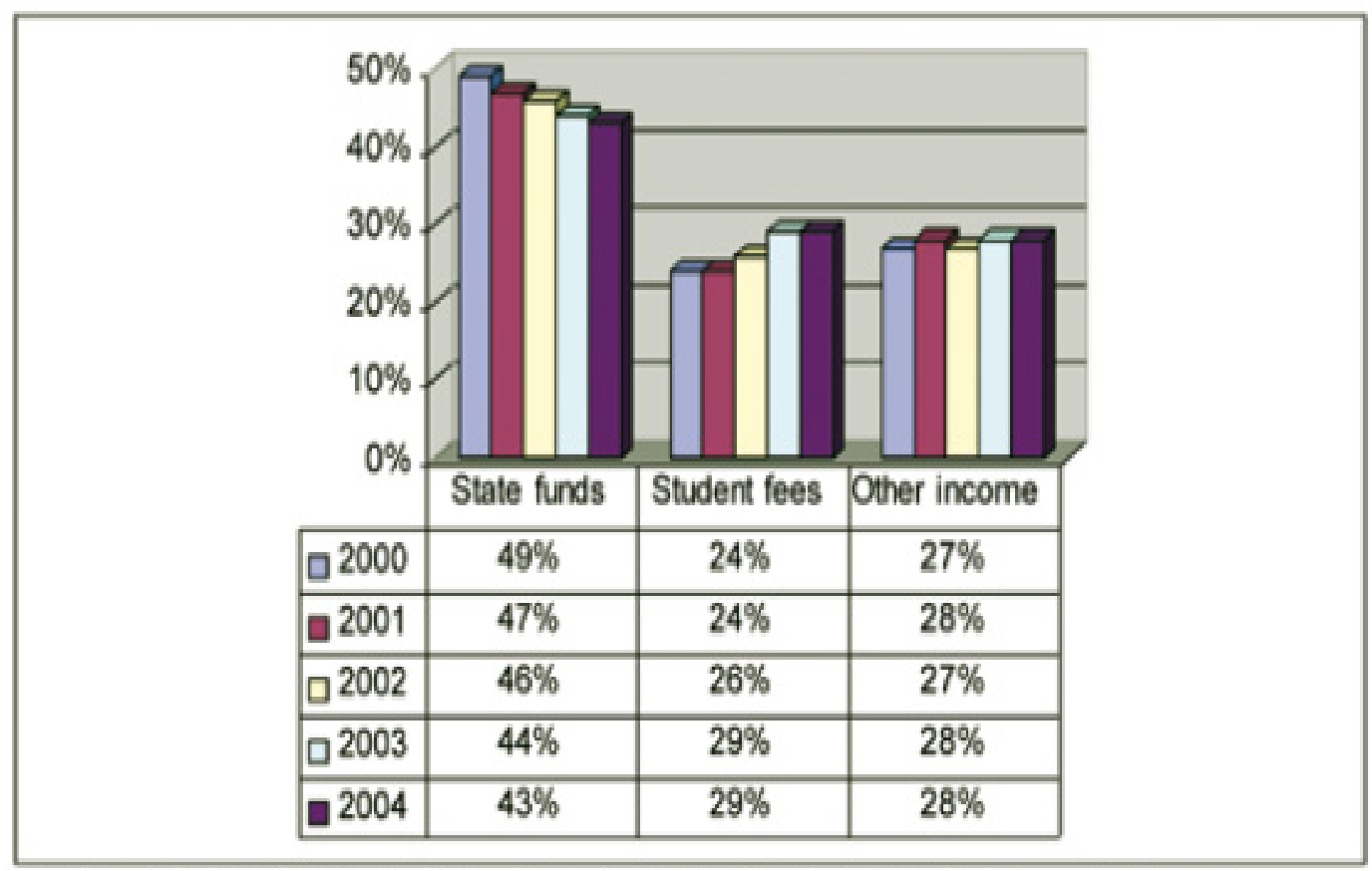

Source: HESA (2008) based on HEMIS data provided by Department of Education (2007)

Figure 1: Sources of Income for higher education institutions in South Africa

The Namibian context has not been different either as exemplified by the table below. As noted earlier, funding in higher education has continued a gradual slide leading to increased tuition fees on the one hand. The depiction jointly shows the sources of income for both the University of Namibia and the Polytechnic of Namibia. 


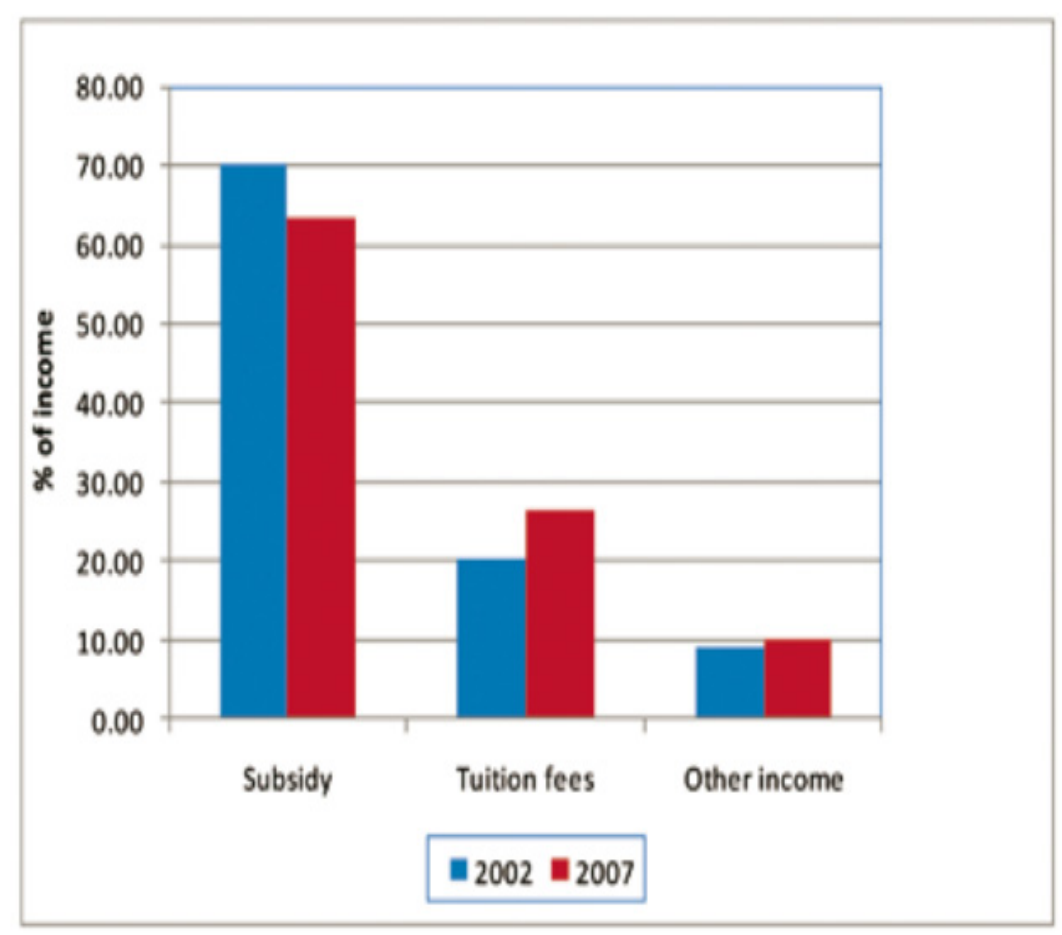

Figure 2: Sources of Income for higher education institutions in Namibia (Source: Sheppard et al (2009)

\section{The Economic Challenge in Higher Education}

Classical liberals will most likely argue that the days of centralised governance of higher education are over and that the role of government must be found in presenting students with timely and relevant information upon which economic choices can be made thus benefitting students from different backgrounds. It has been argued that universities do not necessarily have to charge same fees as their capacities, abilities and costing mechanisms vary. In pure economic theory the argument for free higher education is unsustainable and therefore difficult to advance. Other Inquiries into Higher Education have further noted that graduates on average have significantly higher earnings than non-graduates hence the view that they should bear much of the cost since their education is perceived as future investment (Dearing Report, 1997). Barr (2002) concluded that since higher education created social and national benefits it is right that there should always be a taxpayer contribution. However, he also noted that given the robust evidence on private rates of return to predominantly middle-class participants, excessive reliance on public funding is inefficient, regressive, and to some degree unjust.

In most countries there has been a concerted effort to institute measures such that higher education costs are shared between the graduate and the state. In educational programmes such as nursing and teacher training, which are often deemed essential by the state in its pursuance of national socio-economic goals, heavy subsidies and full grants have often been allocated in these fields. Namibia has also made tremendous strides in this area offering 
grants and subsidies particularly in teacher education (Namibia Ministry of Education, 2012). With the ever rising enrolments in higher education most governments have struggled to provide public funding to match the rising demand for higher education thereby necessitating the need for additional private funding.

\section{Higher Education as a Public Good}

Given the challenges in financing higher education there are those who will seek to restate their question as to whether higher education is a public good that should largely be funded by the state. Jandhyala \& Tilak (2008) argue that higher education institutions have multiple objectives and they are not just economic but produce multiple, varied types of outputs, some tangible and many not. The benefits of higher education are seen as going far beyond private interests since it unlocks the potential at all levels of society. Even though some may consider basic education to be more of a public good, it is argued that higher education in its 'nation-building' role, which is of public interest, is in many ways a public good nonetheless (Levin, 1987; Tomlinson, 1986). Public goods like higher education may not be satisfactorily provided by markets in a manner that satisfies social demand in view of profit motives (Jandhyala \& Tilak, 2008). The raging argument as to whether higher education is public good is seen by some as unnecessary and mischievous (Levin, 1987; Jandhyala \& Tilak, 2008), and may be fomented by capitalistic interests with profit motives (ESIB, 2000).

\section{Quality Dimensions on Access}

The gradual decline of state subsidies as noted earlier coupled with the rise in tuition and hostel fees creates dimensions which impact on quality indicators in higher education. These indicators take into account the quality of students, teachers, infrastructure, student support services, curricula, assessment, learning resources and Management and Governance (Ullah, Ajmal, \& Rahman, 2011). At a global level, the internationalization, marketing, expansion and exportation of higher education has brought concerns on quality provision.

At the University of Namibia the senate thus approved an establishment of a Centre for Quality Assurance and Management (CEQUAM) in January 2010 to be incorporated into the UNAM structures. The centre was thus tasked to coordinate the implementation of a formalized quality assurance system and processes in collaboration with the National Council of Higher education (NCHE) to guarantee that the institution offers quality services to its clients, vis-à-vis: students, parents, guardians, employers, government, other HEI's, and NGOs. CEQUAM thus developed a policy from an understanding that Quality Assurance is an all-embracing term referring to an on-going, continuous process of evaluating (assessing, monitoring, guaranteeing, maintaining, and improving ) the quality of a higher education system (CEQUAM, 2010).

Now that the Government through the Ministry of Education promulgated a law that allows formerly disadvantaged population groups to have greater access to higher education, this 
compels UNAM as an institution of higher learning to align its quality processes and mechanisms to meet the challenges of rising student numbers. This entails that UNAM should provide the necessary administration, support and academic services from the time when students enter UNAM (as inputs), during their study programs (as throughputs) and until graduation (as outputs).

The call for quality enhancement is also a result of Namibia's Vision 2030, in which the government is advocating for a well-educated Namibian workforce that will drive a knowledge based economy (National Planning Commission Secretariat 2004).

\section{Methodology}

The research followed an interpretive approach, using qualitative methods (Cohen, Manion, $\&$ Morrison, 2000), since the aim was to explore perceptions and meanings and their associated effects upon the people's experiences within the identified participants. Using semi-structured questionnaires, the study performed snowballing on 25 school leavers since this group was difficult to track. A few school leavers identified by the researchers led to the identification of more others. Purposive sampling accounted 20 grade 12 students (seen as prospective higher education students), 10 university lecturers (who actively involved with first year students' teaching and admissions) and 50 first and second year university students, whose memory was seen as still fresh in experiencing access challenges. There were also 3 interviews conducted on university administrators. 2 of them deal direction with students' admissions and challenges of access and the other is a senior manager familiar with policies on access. Such triangulation on participants sought to enhance validity as well as establish understanding on key issues inhibiting access and impacting the quality of education in Namibian higher education. Using Critical Discourse Analysis (CDA) the study formed themes for discussion so as to describe and capture the challenges inherent. Discourse is often used to refer to patterns of meaning which organize various symbolic systems human beings inhabit (Parker, 1999).

\section{Discussion of Findings}

While advancing a view to increase equitable access to university education, the study observed that there are quality implications to this demand. The discussion on findings below therefore captured participants' perceptions on challenges of access to higher education and how the impact on quality at the University of Namibia.

\subsection{Students funding}

This study noted that while considerable efforts have been made to promote access to education, this has primarily been confined to basic education. Policies in Namibia have promoted equality in education consistently, particularly with regard to areas such as disabilities and special needs education, but with no or little attention paid to access to higher education. The primary concern of higher education institutions has been competitiveness and 
their focus is on attracting the best students, who are rarely from marginalised families, as these often struggle with financial demands, social challenges, absenteeism, alcohol abuse, and lack of motivation, among other reasons.

The study recommended that due to the strong indications that poverty is a serious barrier to accessing higher education, everyone who qualifies and is admitted to a higher education institution should be awarded a loan through the Namibia Students Financial Assistance Fund (NSFAF) and be motivated and counseled.

The NSFAF provides study loans only to needy Namibian students at recognized institutions of higher learning (full-time not part-time). Such assistance covers tuition, textbooks, registration fees and related educational expenses/ costs at rates as may be determined and approved by the NSFAF Board from time to time. Only students whose combined parental/guardian annual earnings/ gross salary is below N\$150 000 (basic salary plus allowances and other benefits minus income tax and pension fund contributions) qualify. Exception can be made in cases where parents/guardians are already paying for other children at any other recognized tertiary institution. An effort is made to ensure fair distribution of students from all political regions. Repayment of the study loan is only done when the student has found employment, is earning a threshold salary or has breached his/her contract, among other reasons.

The NSFAF policy does not make provision for post-graduate studies except in the form of scholarships offered by friendly governments and/or international organisations through bilateral agreements with the Government of Namibia. Once the study loan beneficiaries have completed their studies, they are required to fulfil their social obligation and honour their contracts by repaying their loans. Removing interest on subsidies may be essential in solving funding problems for a number of students, a move which may strategically aid quality efforts as well as boost equitable access. Flexible fees may also be introduced to reflect diversity and arrest downward spiral of quality, making it possible for students from poor backgrounds to receive grants and scholarships thereby inspiring more schoolchildren. In high income countries such as the United Kingdom where the threat of student debt is also high, it has been argued that loans should be adequate to cover living costs and tuition fees such that higher education access is free at the point of use, thus simultaneously relieve students from poor households.

\subsection{Career guidance and counseling}

Career guidance and counselling as a non-promotional subject was in practice not taught in most schools. The reasons are twofold: that is, 1 . by virtue of its classification as a non -promotional subject and, 2. the lack of trained teachers to effectively teach the subject, thereof. It was only two years back or so when the Namibian Ministry of Education decided to address this problem by creating permanent teaching posts in nearly every school for teacher counsellors. Hence, interested teachers who had undergone rudimentary training at workshops on career guidance and counselling were offered such positions on permanent basis to focus solely on the teaching of the subject. This implies that many school learners and leavers before this policy was implemented were obviously deprived of career guidance 
and counselling services thus depriving them access strategies to higher education. Consequently, some prospective students find themselves in their current predicament due to lack or poor career guidance and counselling while schooling. Hopefully, the current cohort of teacher counsellors, though employed on full time basis will be exposed to more formal training to effectively render professional counselling services and career guidance to their learners.

\subsection{Examinations administration}

It is noted that the corporate image of UNAM has been blemished in this area due to the challenge of administering examinations where student numbers have sharply risen but unmatched with resources and adequate systems. The local Newspapers have thus publicized numerous articles that apparently do not portray the good image of the university in so far as the examination processes and access issues are concerned (The Namibian 2012; The Namibian, 2004); The Namibian 2004a). Students have also expressed their dismay on how some examinations are conducted due to wrong timetabling and writing wrong papers during exams. Lecturers on the other hand have continued to share strong reservations on the manner in which examination papers are set and dispatched to examination centres and satellite campuses. For example, some examination papers continue to be sent from Windhoek main campus to satellite campuses via e-mail or fax while students are already seated for the examinations. The aftermath of examinations writing by students is also another area of concern. Due to enormous examination scripts, some lecturers delay in marking some examination scripts and consequently fail to enter the marks on the UNAM data-base system on time thereby disadvantaging students. The Examinations unit may need to drastically review its examinations processes and mechanisms, channelling adequate resources, in order to conform to internationally best practices where quality is not compromised in terms of quality standards of services that UNAM has set for itself as institution of higher learning.

\subsection{External studies}

The Centre for external studies at the University of Namibia has been at the centre of improving access to higher education, offering numerous courses to higher education prospective students. But the lack of qualified tutors has hampered progress immensely, hence contributing to the dissatisfaction of their students and to a regressive trajectory in equitable access to higher education. This is in sharp contrast with UNAM's set goals of providing quality teaching and learning services in order to mould future leaders and administrators for a knowledge based society.

\subsection{Irrelevance of qualifications}

Currently, UNAM, Katima Mulilo campus has only one faculty, namely the Faculty of Education. According to some respondents especially from the private sector indicated that UNAM should strive to offer more programs other than education because not all prospective students are interested in joining the teaching profession. Some respondents need courses that are business oriented and directly linked to their working environment or jobs. Unfortunately, our local UNAM does not offer such courses whereby the institution loses its potential students to franchise institutions, instead. 
10.6 Poor households

After successfully completing Grade 12, some learners find it difficult to access university education because they cannot afford to pay the exorbitant tuition fees at tertiary institutions because of the low socio-economic status of their parents or guardians. Some prospective students are forced by necessity to seek temporary employment or engage in small businesses to raise money for tuition and other related costs. Unfortunately, some of them struggle to raise such funds and end up losing interest in pursuing further studies.

\subsection{Admission requirements}

Some Grade 12 leavers who are currently working pointed out that the admission requirements are definitely one of the main inhibiting factors to access university education as most of them did not meet the admission requirements of a minimum of 25 points with at least a $\mathrm{C}$ or better in English. Hence, some were working in order to upgrade their symbols by studying through Namibia College of Learning (NAMCOL). Despite having passed other content, subjects such as English and Mathematics are seen as the most difficult and thus further inhibit access to higher education.

\subsection{Lack of qualified lecturers}

According to the UNAM staffing policy, lecturers are supposed to be in possession of Masters' degrees to be able to teach students studying for junior and honours' degrees. Currently, less than half of the lecturers are in possession of such qualifications which implies that quality teaching and learning does not meet set quality frameworks. It is noted that most lecturers are upgrading their qualifications and this should be encouraged. Where necessary, UNAM should ensure that qualified lecturers are recruited and appointed in competition with others in accordance with UNAM's staffing norms.

\subsection{Decentralisation of management of UNAM and courses offered}

The notable establishment of satellite campuses (some former colleges of Education) has been welcome as a measure to improve equitable access. However most respondents felt that there is further need to decentralize some courses and programmes from main campus so at to offer choices at satellite campuses. Most prospective students are discouraged by the excessive cost of accommodation, meals and transport at main campus thus negatively affecting access. In former colleges of Education for example, only education courses are offered posing great difficulty for those who may want to pursue other programmes. Some lecturers and students also felt that the centralised management system of the university, in view of massive distances between campuses was cumbersome and affecting quality decision making.

\subsection{Lack of information / guidance to prospective students}

Almost two years after the UNAM Katima Mulilo campus was established, some respondents do not know how many courses UNAM is offering. Perhaps, UNAM as a corporate need to adopt a business oriented attitude and vehemently market its products and services to reach as many prospective students as possible. 


\subsection{Admissions}

CEQUAM has called on all departments, sections, centres and units to establish QA committees that will conduct self-evaluations to foster improvement in service delivery. For example, despite the ever-increasing number of students annually at UNAM, the recruitment process is relying heavily on the traditional trends of completing hard copies of application forms which is rather out-dated. Though simple, the traditional process has some limitations. Firstly, not all prospective students will have easy access to such documents if one takes into account how sparsely the Namibian population is. Secondly, dispatching such application forms is also another inhibiting factor especially for students from impoverished families who may not have an application fee available at the time of application. These problems are further compounded by the fact that provisionally accepted students have to stand in very long queues to finally register for admission. Such slow and unfriendly processes may eventually lead to prospective students enrolling at other institutions that have less rigorous recruitment processes such as on-line registrations.

\subsection{Teaching and learning facilities}

The physical resources that are meant to support teaching and learning such as lecture rooms, laboratories and libraries are still wanting. There are structures that were built to accommodate a limited number of students some years back and cannot cope with annual increment of students' enrolment. For example, a lecture - hall that is supposed to accommodate at least ninety students still has no PA system. A lecturer is expected to lecture at the top of his/her voice for the sake of students seated at the back of the lecture hall as there is no sound system in place. The library and the laboratories lack the necessary materials needed both by lecturers and students alike. If such materials are available, they are often supplied in small quantities which often lead to a continuous shortage of required materials such as prescribed books, chemicals, etc.

\section{Conclusion}

The research study examined the challenges on equitable access to higher education as enshrined in the national constitution of Namibia and the caveats facing the Higher education institutions in their quest to provide access to formerly disadvantaged citizens. The role of Higher education institutions and the international trends of Commodification were also examined by comparing common trends among various countries including Namibia. Finally, an analysis of respondents' perceptions was conducted to establish the challenges faced by prospective students and also by institutions on access and quality provision. The study noted that while enrolments were rising, inequitable access to higher education still remained. The study advanced a view of a balanced growth, where equitable access and quality education provision matched rising student numbers, as opposed to a false choice between general access and quality provision. 


\section{References}

Ajayi, J. F. A., Goma, L.K.H., \& Johnson, G. A. (1996). The African Experience with Higher Education. Higher Education, 35(4), 473-474.

Bailey, R. (2000). Teaching Values and Citizenship Across the Curriculum. London: Kogan Page.

Barr, N. (2002). 'Funding Higher Education: Policies for Access and Quality'. House of Commons, Education and Skills Committee, Post-16 Student Support, $6^{\text {th }}$ Report of Session 2001-2002, HC445, (TSO, 2002), pp. Ev. 19-35. London: House of Commons

Brennan, J. (2005). The Social Role of the Contemporary University: Contradictions, Boundaries and Change," Ten Years On: Changing Education in a Changing World, Center for Higher Education Research and Information. Milton Keynes: The Open University.

CEQUAM, (2010). Quality Assurance and Management Policy (CEQUAM). Windhoek: University of Namibia.

Cohen, L., Manion, L., \& Morrison, R. (2000). Research Methods in Education. London: Routledge \& Falmer. http://dx.doi.org/10.4324/9780203224342

ESIB, (2012). Commodification of Education Introductory Information. Retrieved May 18, 2012, from http://www.aic.lv/bolona/GATS/ESIB_Info_sheet_on_GATS.pdf

Furlong, A., \& Cartmel, F. (2009). Higher Education and Social Justice. Buckingham: Open University Press.

Human Development Report. (2011). Human Development Report, Sustainability and Equity: A Better Future for All. Retrieved May 19, 2012, from http://hdr.undp.org/en/media/HDR_2011_EN_Complete

Jandhyala B., \&. Tilak, G. (2009). Higher education: a public good or a commodity for trade? Commitment to higher education or commitment of higher education to trade. Retrieved July 18, 2012, from http://www.kritischestudenten.nl/wp-content/uploads/2011/09/higher-education-a-publicgood-or-a-commodity1.pdf

Levin, H. J. (1987). Education as a public and a private good. Journal of Policy and Management, 6(4), 628 - 641. http://dx.doi.org/10.2307/3323518

Matengu, K. (2010). In Pursuit of Access with equity in the Higher Education System in Namibia. Windhoek: Namibia Ministry of Education

Namibia Ministry of Education, (2012). Namibia Students Financial Assistance Fund Retrieved November 20, 2012, from http://www.moe.gov.na/m_dir_viewdirectorate.php?id=27\&directorate=Namibia $\% 20 \mathrm{Stu}$ dents\%20Financial\%20Assistance\%20Fund 
Namibia Ministry of Education, Culture \& Training, (1993). Toward Education for All. Windhoek: Gamsberg Macmillan.

Namibia Supreme Court, (1990). Constitution of the Republic of Namibia. Retrieved July 18, 2012, from http://www.superiorcourts.org.na/supreme/nam_constitution.html

Namibian Economist, (2012). 'Poly asks for more funding'. Retrieved October 14, 2012, from http://www.economist.com.na/general-news/531-poly-asks-for-more-funding

National Council for Higher Education, (2009). Quality Assurance System for Higher Education in Namibia (Final Draft) December 2009. Windhoek: NCHE.

National Planning Commission Secretariat, (2004). Vision 2030. Windhoek: National Planning Commission GRN.

Okwakol, M. J. N. (2012). Examining Challenges of Quality Assurance in Science and Technology Education in African Universities. Johannesburg: AMC International

Parker, I (1999). Critical textwork: Introduction to varieties of discourse and analysis. Buckingham: Open University Press.

Saint, W. S. (1992). Universities in Africa: Strategies for stabilization and revitalization. Washington DC: World Bank.

SARUA, (2012). Higher Education Funding Frameworks in SADC Retrieved July 18, 2012, from http://www.sarua.org/?q=content/chapter-3-higher-education-funding-frameworks-sadc

Sheppard, C., Calitz, E., Steyn, G., \& Brooks, M. J. (2009). Funding Framework Proposals for Public Higher Education Institutions in Namibia, Final Report. Windhoek: NCHE.

Steyn, G. (2011). Access to and funding of Higher Education - A General overview (public lecture) Retrieved August 15, 2012, from http://www.nche.org.na/download.php?file=dldocs/1351...pdf

Stronach, I., Sirca, N. T., \& Dimc, N. (Ed.) (2000): Ways towards quality in education. Slovenia: Open Society Institute.

The Economist, (2011). Paying for Higher Education; Race to the top, Retrieved May 18, 2012, from http://www.economist.com/node/18586968

The Namibian, (2004). UNAM scam: aggrieved Angolans say 'not us'. Retrieved July 13, 2012 , from http://www.namibian.com.na/index.php?id=28\&tx_ttnews\%5Btt_news\%5D=7018\&no_c ache $=1$

The Namibian, (2004a). No money, no exams, no results. Retrieved August 18, 2012, from http://www.namibian.com.na/index.php?id=28\&tx_ttnews\%5Btt_news\%5D=7393\&no_c ache $=1$

The Namibian, (2011). Higher Education Deserves More Focus. Retrieved October 20, 2012, 
from

http://www.namibian.com.na/news/full-story/archive/2012/july/article/higher-educationdeserves-more-focus/

The Namibian, (2012). 'UNAM examinations in chaos again'. Retrieved July 19, 2012, from http://www.namibian.com.na/index.php?id=28\&tx_ttnews\%5Btt_news\%5D=92446\&no_ cache $=1$

Tomlinson, J. R. G. (1986). Public education, public good. Oxford Review of Education, 12, 211-222. http://dx.doi.org/10.1080/0305498860120301

Trow, M. A. (2005). Reflections on the Transition from Elite to Mass to Universal Access: Forms and Phases of Higher Education in Modern Societies since WWII Retrieved February 18, 2012, from http://escholarship.org/uc/item/96p3s213

Ullah, M.H., Ajmal, M. \& Rahman, F. (2011). Analysis of Quality indicators of higher education in Pakistan. Retrieved May 18, 2012, from http://www.intconfhighered.org/FINAL\%20Ullah\%20full\%20text\%20.pdf

UNAM Strategic \& Physical Planning, (2012). Universisty of Namibia's Annual Reports, Windhoek: University of Namibia

UNDP Report (2008). $2^{\text {ND }}$ Millenium Development Goals Namibaia 2008. Retrieved July 26, 2012, from http://www.undp.org.na/SharedFiles/Download.aspx?pageid=9\&fileid=60\&mid=72

UNESCO, (1998). Higher Education in the Twenty-First Century: Vision and Action, World Conference on Higher Education Retrieved October 18, 2012, from http://www.unesco.org/education/educprog/wche/declaration_eng.htm

World Bank. (2008). World Development Indicators 2004 and 2008. Washington, DC: World Bank

Zeleza, P. T., \& Olukuushi, A. (Ed.). (2004). African Universities in the Twenty-first Century - Council for the Development of Social Science Research in Africa, Pretoria: UNISA Press.

\section{Copyright Disclaimer}

Copyright reserved by the author(s).

This article is an open-access article distributed under the terms and conditions of the Creative Commons Attribution license (http://creativecommons.org/licenses/by/3.0/). 